\title{
An investigation of Indian secondary level students' alternative conceptions of water pollution
}

\author{
Animesh K. Mohapatra ${ }^{1}$ and Mriganky Bhadauria ${ }^{2}$ \\ ${ }^{1}$ Regional Institute of Education (NCERT), Unit-IX, Bhubaneswar-751022, Orissa, India. \\ ${ }^{2}$ Regional Institute of Education (NCERT), Puskar Road, Ajmer-305004, Rajasthan, \\ akmrie01@yahoo.co.in; mriganky@rediff.com
}

\begin{abstract}
The prevalence of the ideas of secondary students (class $\mathrm{X}$ ) about causes, consequences and remedies of water pollution was determined using a closed form of questionnaire. Many of the Indian students in the present study were unaware of the devastating effect of deforestation, chemical fertilizers employed in agricultural fields, offshore mining, smoke, volcanic eruptions, weathering of soil and rocks on pollution of water and its impact on humans viz. blindness, DNA damage, deformities of bones etc. Prevalent alternative conceptions and misconceptions were: sewage, pesticides, soil erosions do not pollute water; water pollution causes acid rain; radioactive waste dumped in oceans and greenhouse effect could minimize water pollution and BOD of sewage water is very less than that of pure drinking water. It exposes the lacuna in Indian educational system and suggests a strong drive to displace misconceptions at the early stage of learning itself, before they become embedded in an alternative conceptual frame work.
\end{abstract}

Keywords: India, secondary school, science education, water pollution, environment, awareness.

\section{Introduction}

"Green" issues have gained a high profile and the general publics become more aware of the environmental problems that challenge humankind. Some of these problems of a global scale which involve changes in the biosphere are: global warming and ozone layer depletion. Other problems are of a relatively 'local' nature: acute pollution of a particular habitat would be an example. The solution to local problems requires major changes in human lifestyle (Houghton et al., 1990; Tickell, 1991; Francis et al., 1993).

Children now at school will become decision making citizens at a time when these local environmental problems will be of gaining much social importance. Therefore educating children on these issues becomes paramount importance. At the same time it is fundamental to know how much the students know, how they feel and what they are doing regarding environmental matters. The need for such information has been recognized in other countries (Towler \& Swan, 1972; Perkes, 1973; Eyeers, 1975; Bohl, 1976; Richmond, 1976; Blum, 1984; 1987; Cortes, 1991; Lau, 1992) as it would be useful for better planning, organization and implementation of environmental programmes and projects. In addition, the information can provide educators with some insight into the curriculum content of environmental education.
Rapid increase in the world population within last 3035 years, improvement in industry and technology, natural resources started to extinct have let environmental problems to come to the agenda. Some significant matters must be produced in an equal amount they are exploited in order to lead liveliness in the nature without any interruption. These matters having an ecological significance of 'give and take' between living beings and their environments. These matters complete their circulation by following certain orbits by means of solar energy. All matters are continuously reused by living things through cycle. Most significant ones of these matter required for living things and to be transferred are water, oxygen, nitrogen, carbon, phosphorous, sulphur (Cardak, 2009). Circulation of matter in cells, tissues, system and organism, chemical reactions, sustainability and consistency of the structure are ensured with water. Water is so significant from this point. But now a days the water resources are becoming polluted at a very high scale and producing alarming effects on human too.

\section{Procedure}

This study aims to explore the secondary students' (class X) understanding of an environmental problem, the water pollution. A closed form questionnaire was designed containing 32 questions in the form of statements distributed in three sections. Section A measures the students' level of understanding about the causes of water pollution contained 10 questions of which six were scientifically acceptable and five are nonacceptable. Section 'B' contains 11 questions on consequences of water pollution in which 6 are scientifically correct and 5 are scientifically incorrect statements. The section C measures about students' attitudes towards the prevention or what could be done to reduce water pollution contained seven scientifically true and four unacceptable questions. In each of the sections, the scientifically acceptable and scientifically incorrect statements were interspersed randomly.

Secondary schools were identified randomly. 651 students of class $X$ were asked to complete the questionnaire during free periods. They were asked to respond each of the statements in the questionnaire by ticking the box of their choice labeled, I am sure this is right, 'I think this is right', 'I don't know', 'I think this is wrong' and ' I am sure this is wrong'.

\section{Results and discussion}

A total of 651 secondary students of class $X$ completed the questionnaire. Of the 651 students, 376
Sci. Technol. Edu.

CIndian Society for Education and Environment (iSee)
"Environmental awareness among students" http://www.indjst.org
Mohapatra \& Bhadauria Indian J.Sci.Technol. 
were boys and 275 were girls. The responses to the

Vol.2 No. 11 (Nov. 2009)

ISSN: 0974- 6846 questionnaire statements about the causes,

soluble in water when enter the atmosphere reacts with

Fig. 1. Students' responses to scientifically acceptable statements about causes and sources of water pollution

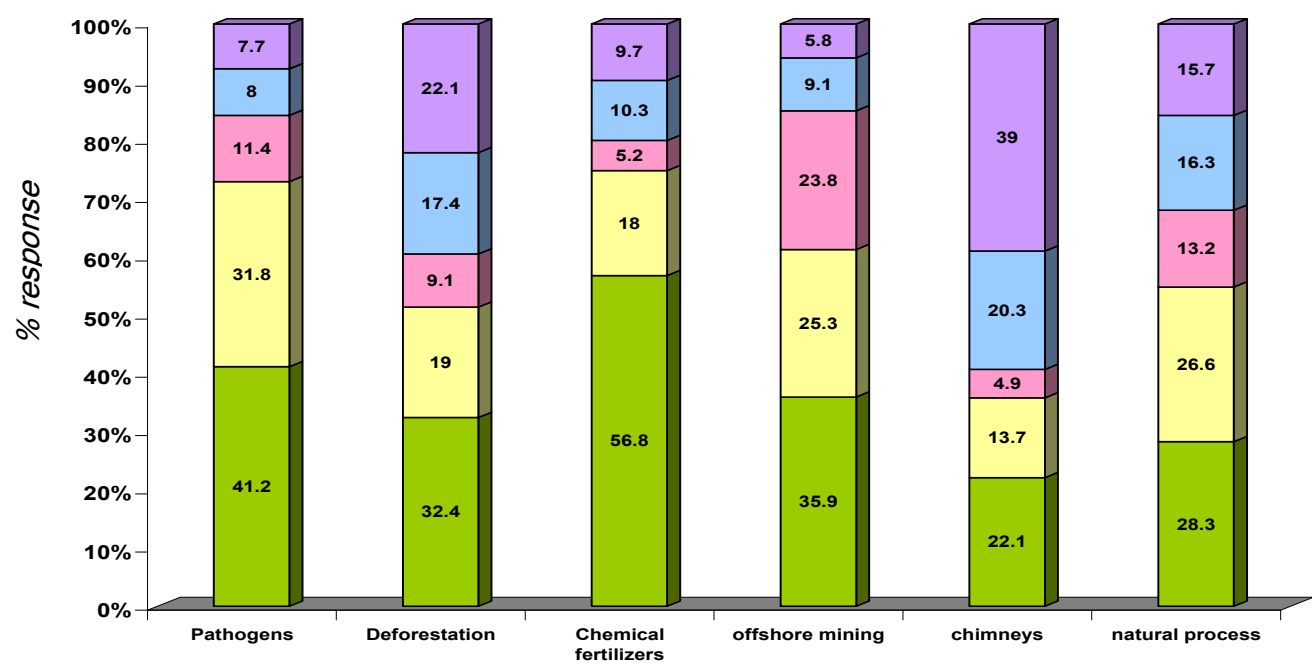

Boxes in a column represents: / box (bottom) = I am sure this is right; // box= / think this is right; III box= I don't know; IV box= I think this is wrong; $V$ box (top) = I am sure this is wrong

consequences and cures of water pollution are shown graphically in Fig. 1 to 6 . In these figures five different colour shades are used which represents 'sure right', 'think right', 'don't know', 'think wrong' and 'sure wrong' responses from bottom to top. In the description below, the percentage mentioned are either for combined 'sure right' and 'think right' responses that is for those who affirmed the statement or for the combined 'think wrong' and 'sure wrong' responses that is for those who do not affirmed the statement.

\section{Students' ideas about causes of water pollution}

The students' responses to the statements of section $A$ of the questionnaire are shown in Fig. 1 and 2. About three-quarter of the students knew that pollution of water is caused by pathogens like bacteria (73\%). More than one-half of the students affirmed that in addition to the above, deforestation (51.4\%), off shore mining and shipping (61.2\%), weathering of soils \& rocks and volcanic eruptions (54.9\%); onethird of the students $(35.8 \%)$ could link smoke coming out from chimneys with water pollution. In view of the complexity and its intangible nature, one might anticipate that children will find this concept difficult to understand. Oxides of nitrogen and sulphur present in smoke which are highly

Sci. Technol. Edu.

CIndian Society for Education and Environment (iSee)
"Environmental awareness among students" http://www.indjst.org increases the acidity of water bodies, thereby causing harm to aquatic ecosystem. The most common misconception, however, held by many of the students were that hot waste water released from thermal power plants $(68.2 \%)$, soil erosion (44.4\%), pesticides used in agricultural fields $(36.3 \%)$ and sewage (24\%) would not pollute water.

Students' ideas about consequences of water pollution

The data for the second section of the questionnaire about consequences of water pollution are shown in Fig. 3 and 4. It is well known to many of the students that water pollution would result in reduction of oxygen level in water $(76 \%)$ and loss of biodiversity (76.3\%). Nearby one-half of the students agreed that pesticides runoff from fields would lead to blindness in fishes (53.6\%), high fluoride content in potable water would result in deformities of bone and DNA damage (53.9\%)d and blue baby syndrome could be due to consumption of polluted water $(44.7 \%)$. Only about one-third of the students (34.6\%) affirmed that certain toxic pollutants present in polluted water could enter into food chain. Surprisingly, one-half of the students (49.7\%) erroneously linked water pollution with acid rain, they thought that water evaporated from polluted water bodies would result in acid rain. Other misconceptions shown by secondary students were that rate of primary productivity

Fig.2. Students' responses to scientifically unorthodox statements about causes and sources of water pollution (Legend as in Fig. 1)
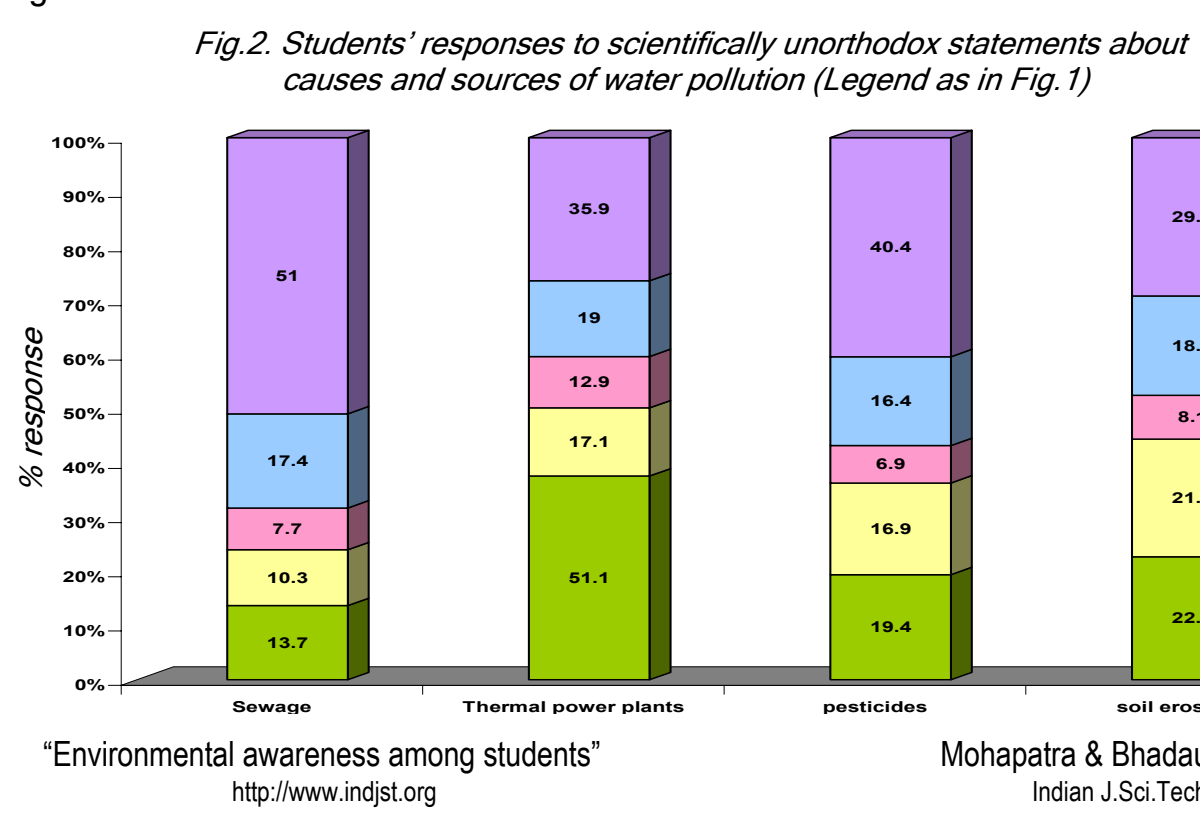

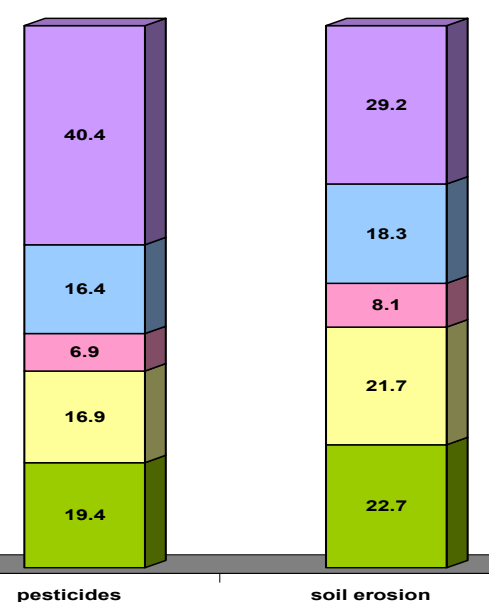

Mohapatra \& Bhadauria Indian J.Sci.Technol. 
increases as water pollution increases in ponds and lakes $(47.7 \%)$, that BOD of sewage water is lower than BOD of pure drinking water $(49.9 \%)$ and that mina Mata disease is caused by cadmium contamination in water $(38.3 \%)$. However, majority of the students $(80.4 \%)$ rightly rejected that water pollution at the surface of water body would not

Fig. 3. Students' responses to scientifically acceptable statements about consequences of water pollution (Legend as in Fig. 1)

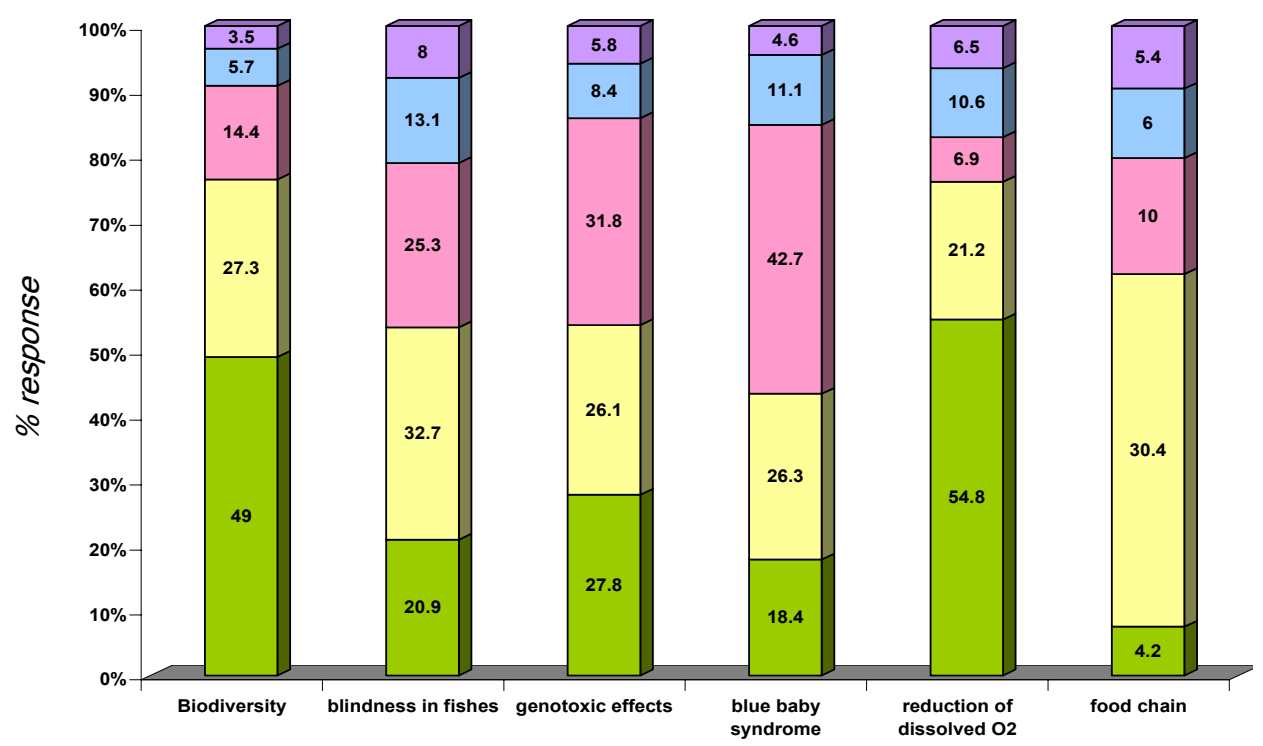

affect submerged life.

\section{Students' ideas about reducing the water pollution}

The data for the responses to statements about actions which might reduce the pollution of water are represented graphically in Fig. 5 and 6 . The results of the present study revealed that children knew that chlorine is used as disinfectant (83.1\%), reverse osmosis system could be used to get rid of the impurities from potable water $(65.7 \%)$ and ferric chloride coagulation system is used to reduce arsenic impurity from water $(61.3 \%)$. In addition to these, they were also aware of the facts that ozone and ultraviolet treatment (41.4\%), water hyacinth $(40.4 \%)$ and peanut husks and cheap waste products of food industry (33.9\%) could be used to purify water. About three-fifth of the children (64.2\%) suggested that sewage could be used in gobar gas plants instead of releasing it into water bodies and this would result in reduced pollution of water. More than one-half of the students erroneously linked greenhouse effect with water pollution. They thought that increase in greenhouse effect
Sci. Technol. Edu.

CIndian Society for Education and Environment (iSee) would reduce water pollution showing poor knowledge about environmental problems. Similarly, one-third of the students $(34.3 \%)$ wrongly thought that by dumping radioactive waste in oceans would minimize water pollution. Some other misconceptions shown by students were that water becomes impure when alum is added $(47.6 \%)$ and infra-red radiations could be used to purify water (29.2\%).

The results of the present study revealed that many of the students are well informed about certain aspects related with water pollution. For example, they are aware of the facts that pathogens, chemical fertilizers, offshore mining, volcanic eruptions causes water pollution and it affects biodiversity, human health and reduces oxygen level of water. However, the results showed several misconceptions prevailing in the mind of students, such as green house effect could reduce pollution of water etc. Misconception is one of the significant factors which affect learning. Misconceptions implies thinking patterns which do not overlap with scientific realities with general meaning, rather contradicted with then and are developed or made sense of by individuals specific to them in their minds (Behar, 2003). Since these thinking patterns developed by
Fig.4. Students' responses to scientifically unorthodox statements about consequences of water pollution (Legend as in Fig. 1)

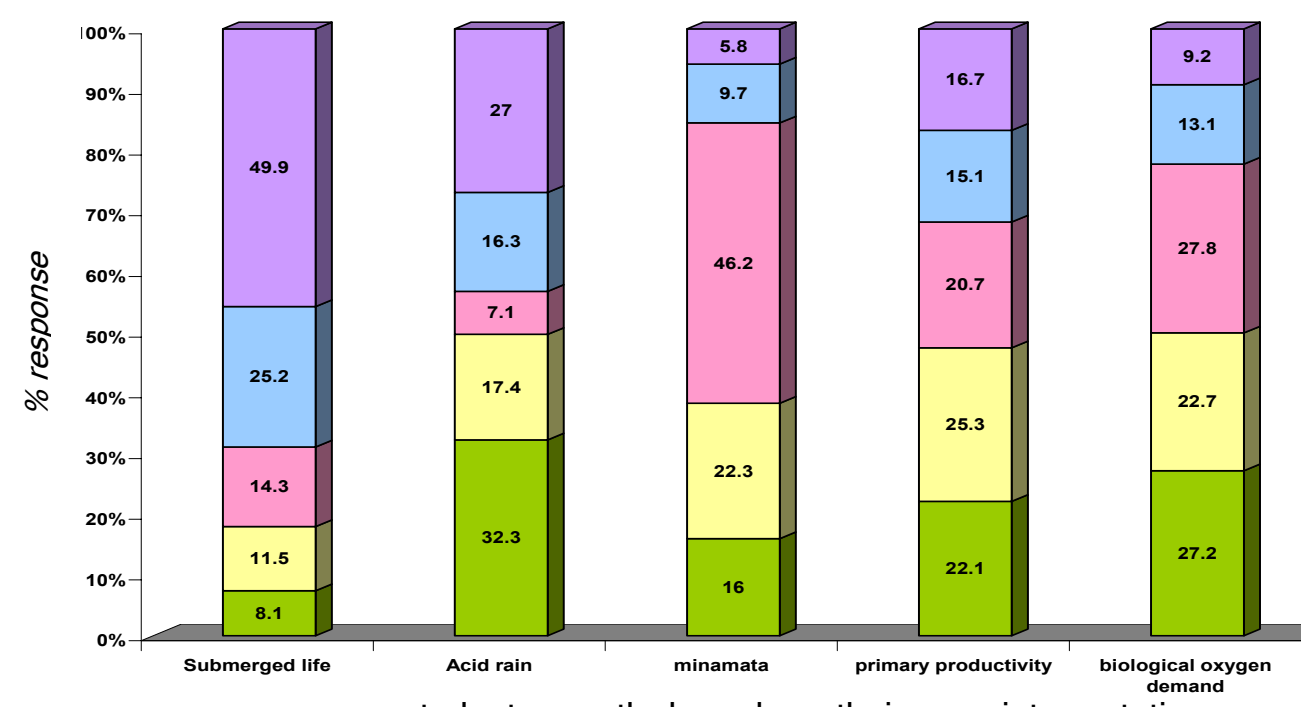

students mostly based on their own interpretations are contrary to scientific realities, they constitute a significant barrier against science education (Wandersee et al., 1994; Tekkaya, 2003). Students usually develop misconceptions as a result of their own interpretations or from some contradictory explanations in school or out of http://www.indjst.org
"Environmental awareness among students"
Mohapatra \& Bhadauria Indian J.Sci.Technol. 
school environments in early periods of their school years (Wandersee et al., 1994; Behar, 2003; Cardak, 2009). Expressions of teachers or those in text books also may lead to concept mistakes or may enhance existing misconceptions of students in some circumstances degrees of fidelity. Such attitudes are important because, although the links between knowledge, attitude and behaviour are far from straight forward, these three domains undoubtedly interact, and it is patterns of human behaviour which are of proximal importance to the
Fig. 5. Students' responses to scientifically acceptable statements about remedies of water pollution (Legend as in Fig. 1)

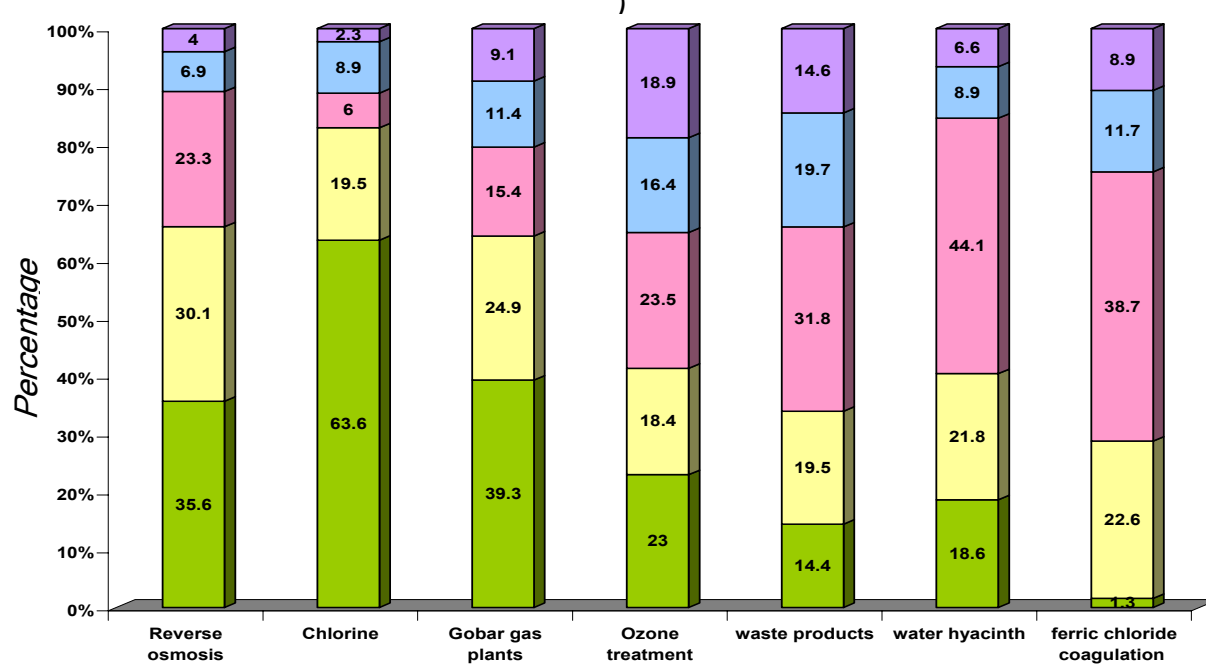
environment.

\section{Acknowledgement}

The authors wish to thank Prof. V. G. Jadhao, Principal and Prof. K.B. Rath, Dean of Instruction, Regional Institute of Education (NCERT) for their valuable comments and encouragement. We also thank principals of various schools for their kind cooperation.

\section{References}

1. Behar M (2003) Misconceptions in biology education and conceptual change strategies. Kuram ve uygulamada Eg. Bil. 3, 55-64.

2. Blum A (1984) What do Israel high school students know and believe about environmental issues? Environ. Edu. Info. 3, 338-48.

(Sewell, 2002). If misconceptions are not detected and compensated, they continue for long years and constitute significant barriers in understanding process. If science teachers and curriculum designers knew students' misconceptions ideas related to science concepts, it might be helpful to prepare effective teaching schemes. In this situation, teachers can play an important role in teaching these concepts (O-Saki \& Samiroden, 1990).

Moreover, with problems of this nature, it is unlikely that the influence on students' thinking will be restricted to the cognitive domain, so they are likely to form attitudes based on ideas from a plethora of sources with varying

Fig. 6. Students' responses to scientifically unorthodox statements about remedies of water pollution (Legend as in fig. 1)

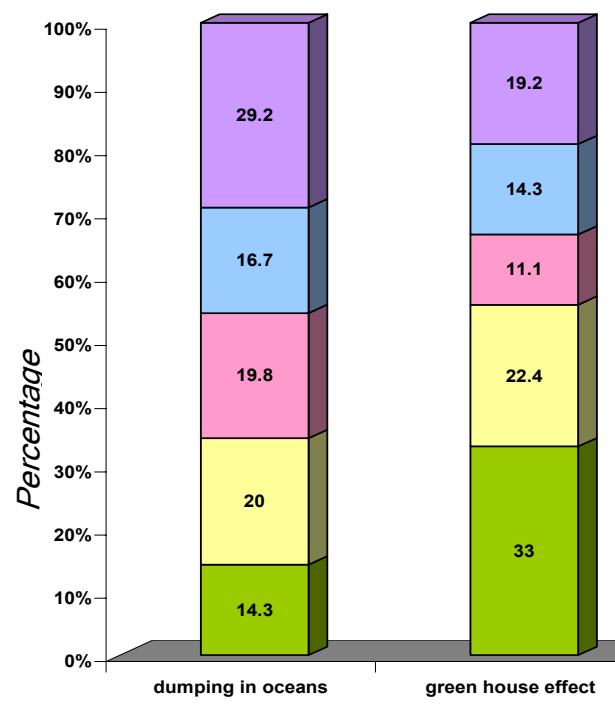

Sci. Technol. Edu.

CIndian Society for Education and Environment (iSee)

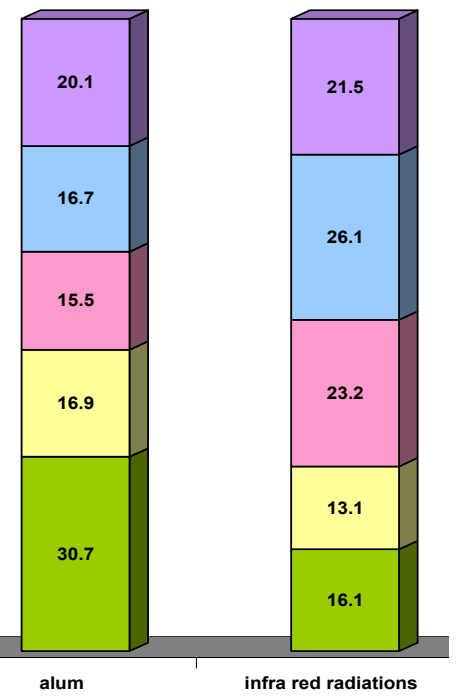

3. Blum A (1987) Students' knowledge and beliefs concerning environmental issues in four countries. $J$. Environ. Edu. 18(3), 7-13.

4. Bohl WB (1976) A survey of cognitive and affective components of selected environmentally related attitudes of tenth and twelve grade students in six midwestern, four southwestern and twelve plains and mountain states. Unpublished doctoral dissertation, the Ohio State Univ.

5. Cardak O (2009) Science students' misconceptions of the water cycle according to their drawings. J. Appl. Sci. 1-9.

6. Carlsson B (2002) Ecological understanding 2: transformation - a key to ecological understanding. Int. J. Sci. Edu. 24, 701-715.

7. Cetin G (2007) English and Turkish pupils' understanding of decomposition. Asia Pacific for Science Learn Teach. 8, 1-1.

8. Cortes LP (1991) A survey of the environmental knowledge, comprehension, responsibility and interest of the secondary level students and teachers in the Philippines. Garland Publ., NY.

9. Ekborg M (2003) How student teachers use scientific conceptions to discuss a complex environmental issue. J. Biol. Edu. 37, 126-132.

10. Ekborg M (2005) Student teachers
"Environmental awareness among students" http://www.indjst.org
Mohapatra \& Bhadauria Indian J.Sci.Technol. 
learning outcomes during science subject matter courses. Int. J. Sci. Edu. 27, 1671-1694.

11. Eyeers VG (1975) Environmental knowledge and beliefs among tenth grade students in Australia. Unpublished doctoral dissertation, Oregon State University.

12. Francis C, Boyes E, Qualter A and Stanisstreet M (1993) Ideas of elementary students about reducing the greenhouse effect. Sci. Edu. 77 (4), 375-392.

13. Houghton JT, Jenkins GJ and Ephraums JJ (1990) Climate change: the intergovernmental panel on climate change scientific assessment. Cambridge Univ. Press, UK.

14. Kali Y, Orion N and Eylon B (2003) The effects of knowledge integration activities on students perception of the earths' crust as a cyclic system. J. Res. Scui. Teach. 40, 545-565.

15. Lau TL (1992) Environmental issues: singapore student awareness. Unpublished academic exercise. Dept. of Geography, Natl. Univ. Singapore.

16. O-Saki KM and Samiroden WD (1990) Students' conceptions of living and dead. J. Biol. Edu. 24, 199207.

17. Perkes AC (1973) A survey of environmental knowledge and attitudes of tenth and twelfth grade students from five great lakes and six far western states unpublished doctoral dissertation. The Ohio State Univ.

18. Richmond JM (1976) A survey of the environmental knowledge and attitudes of fifth year students in England. Unpublished doctoral dissertation. The Ohio State Univ.

19. Sander EO, Jelemenska P and Kattmann U (2006) Towards a better understanding of ecology. J. Biol. Edu. 40, 119-123.

20. Sewell A (2002) Constructivism and student misconceptions why every teacher needs to know about them. Aus. Sci. Teaching J. 48, 24-28.

21. Tekkaya C (2003) Remediating high schools misconceptions concerning diffusion and osmosis through concept mapping and conceptual change text. Res. Sci. Teach. Edu. 21, 5-16.

22. Tickell C (1991) The quality of life: what quality? whose life? Address to the British Association, reported in the Independent Newspaper, p:3.

23. Towler J and Swan JE (1972) What do people really know about pollution? In: Interpreting rnvrionmental issues, research and development in conservation communication. Schoenfeld C (ed.), Madison: Dembar Educational Res. Services. Pp: 245-248.

24. Wandersee JH, Mintzes JJ and Novak JD (1994) Research on alternative conceptions in science. In: Handbook of research on science teaching and learning. Gabel DL (Ed.), MacMillan, New York. pp:177-210. 